\title{
Real presence. Outline of an ecumenical review
}

\begin{tabular}{|c|c|}
\hline \multicolumn{2}{|l|}{$\begin{array}{l}\text { Author: } \\
\text { Werner Klän }{ }^{1,2}\end{array}$} \\
\hline \multicolumn{2}{|c|}{$\begin{array}{l}\text { Affiliations: } \\
{ }^{1} \text { Lutherische Theologische } \\
\text { Hochschule Oberursel, } \\
\text { Systematische Theologie, } \\
\text { Deutschland, Germany }\end{array}$} \\
\hline \multicolumn{2}{|c|}{$\begin{array}{l}{ }^{2} \text { Department of Church } \\
\text { History and Church Polity, } \\
\text { Faculty of Theology, } \\
\text { University of Pretoria, } \\
\text { South Africa }\end{array}$} \\
\hline \multicolumn{2}{|c|}{$\begin{array}{l}\text { Project Leader: G.A. Duncan } \\
\text { Project Number: } 02618958\end{array}$} \\
\hline \multicolumn{2}{|c|}{$\begin{array}{l}\text { Description: } \\
\text { Prof. Klän is participating in } \\
\text { the research project, 'History } \\
\text { of Theological Education in } \\
\text { Africa' directed by Prof. Dr } \\
\text { Graham Duncan of the } \\
\text { Department of Church } \\
\text { History and Church Polity at } \\
\text { the Faculty of Theology, } \\
\text { University of Pretoria, } \\
\text { South Africa }\end{array}$} \\
\hline \multicolumn{2}{|c|}{$\begin{array}{l}\text { Corresponding author: } \\
\text { Werner Klän, } \\
\text { werner.klaen@gmx.de }\end{array}$} \\
\hline \multicolumn{2}{|c|}{$\begin{array}{l}\text { Dates: } \\
\text { Received: } 21 \text { Jan. } 2016 \\
\text { Accepted: } 06 \text { June } 2016 \\
\text { Published: } 31 \text { Aug. } 2016\end{array}$} \\
\hline \multicolumn{2}{|c|}{$\begin{array}{l}\text { How to cite this article: } \\
\text { Klän, W., 2016, 'Real } \\
\text { presence. Outline of an } \\
\text { ecumenical review', HTS } \\
\text { Teologiese Studies/ } \\
\text { Theological Studies } 72(1) \text {, } \\
\text { a3341. http://dx.doi. } \\
\text { org/10.4102/hts.v72i1.3341 }\end{array}$} \\
\hline \multicolumn{2}{|c|}{$\begin{array}{l}\text { Copyright: } \\
\text { (C) 2016. The Authors } \\
\text { Licensee: AOSIS. This } \\
\text { is licensed under the } \\
\text { Creative Commons } \\
\text { Attribution License. }\end{array}$} \\
\hline \multicolumn{2}{|l|}{ Read online: } \\
\hline 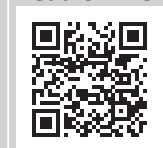 & $\begin{array}{l}\text { Scan this QR } \\
\text { code with your } \\
\text { smart phone or } \\
\text { mobile device } \\
\text { to read online. }\end{array}$ \\
\hline
\end{tabular}

The issue of an adequate description, a conceptual formulation and a theological interpretation of the gift of the Lord's Supper, has been a concern of Christianity since ancient times. The circumspect observation in the Charta Oecumenica (2001) reads: 'Fundamental differences in faith are still barriers to visible unity'. In the light of those difficulties, attempts have been made in recent years to work on a 'Joint Declaration on the Lord's Supper'. All churches and denominations face the challenge to bring that which they learn of Jesus Christ's sacramental presence from the New Testament. Some rapprochements have been achieved in the last decades. Some of those results are discussed in this essay.

\section{Introduction}

The issue of an adequate description, a conceptual formulation and a theological interpretation of the gift of the Lord's Supper, has been a concern of Christianity since ancient times. Arnold Angenendt, in his extensive study on the Sacrifice of the Mass, has presented a wealth of variants of such interpretational processes, ranging from antiquity to the threshold of the Reformation, thereby bringing them up for critical debate with the developments of the Vaticanum II (cf. Angenendt 2013:478-488). The New Testament provides evidence of the ceremony's intrinsic character as that of a meal, Communion as 'becoming one with the person of Jesus Christ'. In baptism, as the 'sacrament of faith', the affiliation with Christ is 'conclusively concluded', while this union experiences 'continual strengthening' in the Sacrifice of the Mass (Angenendt 2013:35). Angenendt argues that the commemoration as based on Christ's command: 'Do this in rememberance of me' should be understood as a process 'from above', in other words not merely as 'recollection' commemorated from a distance or 'subjective remembrance', but rather 'as "visualisation," effected by Christ', of the life, passion and dying of Christ, and therefore the self-sacrifice of his crucifixion (Angenendt 2013:36; 38). His blood is the expiation that the believer has need of and also experiences (Angenendt 2013:48). The only appropriate offering on the part of the Christian community for this process is a thank-and-praise offering, as which it was in fact regarded and practised in the history of Christian liturgy and theology during the first centuries, and is not least expressed in self-offering, in the all-encompassing devotion of a Christian in his day-to-day living (Angenendt 2013:38-42). A 'horizontal dimension' (Angenendt 2013:33) has thereby been added to the 'vertical dimension' (Angenendt 2013:50), which facilitated Christian 'social care' (Angenendt 2013:58) but also necessitated provisions to be put in place for the subsistence of, the sequestration from and readmission to the fellowship of the Christian community (Angenendt 2013:50-63). The early eucharistic prayers still reflect 'the solidarity of all participants', which is founded therein that 'Jesus makes himself present in his flesh and blood for the salvation of all' (Angenendt 2013:470).

Towards the end of the Patristic Age the concept of mystery or rather sacrament and its understanding became instrumental for the 'theological interpretation [...] of the eucharistic bread and wine' (Angenendt 2013:64-70). According to the platonically inspired form-and-image relationship, the association between the body and blood of Christ and the eucharistic elements is understood to lie in 'symbolism', with Augustine being called upon as the Early Church's key witness in this regard; according to this, one does receive the body of the Exalted One, but in such a way that, in the process of eating and drinking, an 'incorporation into the sacrificed Christ' is realised (Angenendt 2013:65-68). Ambrose, on the other hand, espouses a kind of 'metabolism' which represents the transformation of bread and wine into the body and blood of Christ; in both these processes of interpretation the emphasis is now being placed on the question of the 'presentness' of the eucharistic gifts (Angenendt 2013:68f). The early medieval continuation, thus Angenendt, sees a consolidation of the 'realistic' understanding of the presentness of Christ's body or flesh and blood, effected by the word of command of the Lord himself, as is particularly apparent with Paschasius Radbertus (Angenendt 2013:196-201).

Note: This article is translated from the German article 'Realpräsenz. Skizze einer ökumenischen Bestandsaufnahme' by Klaudia Ringelmann. 
It was only in the High Middle Ages, however, that transformation truly became a topic of theological contemplation in its own right. Special emphasis was now placed on the priestly powers of consecration and the theory of transubstantiation (Angenendt 2013:358-400). The priesthood during this time tended to become more and more isolated from the community and, because of the powers of consecration ascribed to it, is also elevated above the populace. Consecration and offering finally converge with Thomas Aquinas; a 'concentration on consecration' occurs (Angenendt 2013:359; 472). This 'revolutionary' development is often accompanied by an understanding of a hyper-realistic nature (Angenendt 2013:360). ${ }^{1}$ By way of contrast, the theory of transubstantiation, as it was codified during the Fourth Lateran Council, constituted an anti-materialistic modification in a manner of speaking; according to Thomas there is no 'corporeality, spatiality and dimensionality' appertaining to the 'substantive' presence of Christ's body and blood in the sacrament, especially considering that it is not the historical body of Christ that is being made present, but rather that a transubstantiation 'into the transfigured body of the Lord' is being effected (Angenendt 2013:365). The thank offering as a means to implement incorporation into the death of the Lord do however now tend to be of secondary importance (Angenendt 2013:367); the 'question of the exposition of the so-called "real presence"' now takes precedence (Pesch 2010:481; cf. Angenendt 2013:373). This results in the elevation and worship of the eucharistic bread, leading to the devout veneration of the 'visible realisation of Jesus Christ himself'; this gave rise to the beginnings of the Feast of Corpus Christi in the thirteenth century (Angenendt 2013:377, 379). The drawback of this development was, on the one hand, that Communion was received less frequently, and, on the other, 'the prohibition of the Communion cup for the laity' (Angenendt 2013:381-389)2; this resulted in a 'degrading of the laity' (Angenendt 2013:475).

The late Middle Ages are finally characterised by an 'understanding of the Eucharist that has become completely and utterly static' (Ratzinger 1967:136; cf. Angenendt 2013:402). A typical demonstration thereof is the theology of the mass of Gabriel Biel (Angenendt 2013:443-452). The Mass is now 'essentially [...] the sacrifice of the Son to the Father' which is executed in a hierarchical setting apart by the priest who, with the body and blood of Christ 'which he has consecrated in the canonical words', essentially makes a sacrifice 'for the salvation of the living and the dead to the most holy Father', a sacrifice admittedly only performed 'indirectly by the populace' (Biel 1965-1967; cf. Angenendt 2013:445). Even if the Mass's ultimate aim is Communion, it is nevertheless essentially a sacrifice, and an atoning sacrifice at that (Angenendt 2013:447). No less a figure than Otto Hermann Pesch is therefore sympathetic to the fact that Luther removed the references pertaining to sacrifice from the prayers of the Mass Canon. Recent Roman Catholic Mass Theology emphasises the 'inclusion of the church into the event of Christ's self offering' (Negel 2005:320; cf. Angenendt 2013:483) and, accordingly, also the priestly ministry of the people of God, the realisation

1.Angenendt (2013:367) cites i.a. the bleeding host of the Middle Ages.

2.Angenendt (2010:473) makes the point that it was only the Roman Catholic Church that mandated this withdrawal of the Communion cup. of which was to be assigned to the ministers of the church (Greshake 1997:423; cf. Angenendt 2013:484).

\section{Lutheran fundamental principles}

For Martin Luther there is no doubt as to the presence of the body and blood of Christ, a presence that is constituted by the creative testamentary Word of Jesus Christ on the way to his death, a Word that retains its power beyond Maundy Thursday and Good Friday (cf. Ringleben 2006:13-31). ${ }^{3}$ The Lord's Words of Institution, being the Word of God, thus have constitutive meaning for the sacrament, seeing that, 'as words of the Creator in the mouth of Christ, they reshape the created, natural elements and, without removing them, elevate them to the new Word-reality appertaining to Christ' (Ringleben 2006:24). It is about a 'being joined to' constituted by the 'identifying "est" (Ringleben 2006:26). ${ }^{4}$ In this process, according to Luther, the 'natural and eschatological body of Christ is being discerned while at the same time applying to one another' (Ringleben 2006:28). ${ }^{5}$ Thus, by virtue of the creative, spoken Word of Christ, a sacramental union occurs with a new quality (Ringleben 2006:30), which remains 'without analogy' in any other instance. ${ }^{6}$

The Confessio Augustana Invariata follows Luther with regards to the identification of the body and blood of Christ with the elements of bread and wine; when reading CA X in a reciprocal epexegesis of the German and Latin edition, the bridge that Melanchton builds with medieval, occidental tradition is obvious: the true body and blood of Christ are present, administered and received 'under the species' of bread and wine.

God's act of institution and his salvific self-pledge are constitutive of the Lutheran conception of the sacrament. Melanchton definitely retains the idea of word-relatedness and symbolism that characterises the Augustinian concept of the sacrament. ${ }^{8}$ Like Luther, he adheres to the determination of the sacrament as being 'visible word' ('verbum visibile') so that its inherent characteristic reside in that which is already implied in the word. ${ }^{9}$ The purport and effect of the word and the liturgical execution of Holy Communion are thereby identical - namely forgiveness of sin and, consequently, renewed communion between God and humans; however, the mode of the impartation, perception and reception of salvation varies. ${ }^{10}$

In the Confession of the Lutheran Church the essence of the Sacrament of the Altar is based exclusively on Christ's Words of Institution on Maundy Thursday. ${ }^{11}$ The real presence of the

3.On this point, see Jobst Schöne (2006:33-49), Das essbare Heil. Was Martin Luther vom heiligen Abendmahl bekennt'.

4.Also with reference to WA 26, 443, 29-31.

5.Also with reference to WA 26, 382, 8-12, cf. WA 26,380, 20-28.

6.Cf. FC SD VII 38, 'inusitata', BSLK, 984; cf. Schöne (2006:42).

7.BSLK, 64

8.Cf. ApolCA XIII 5, BSLK 292f.

9.Large Catechism, Sacrament of the Altar, 8-14; 31, BSLK 709f; 713f.

10. “Idem effectus est verbi et ritus"; „ritus ... est quasi pictura verbi, idem significans, quod verbum. Quare idem est utriusque effectus'.

11.FC SD VII, 42-59, BSLK 985-991; this is also utilised where the consecration is concerned, cf. FC SD VII, 73-82, BSLK 997-1000. 
body and blood of Christ under the species of bread and wine as meal thereby finds its basis in God's order, which is more than just a connection that consists only of the act of its institution. The emphasis on the body and blood of Christ thereby serves to refer, if not to the focus on the sacrificial figure of the Lord, then to the specific focus on his work of salvation. ${ }^{12}$

Also, and particularly where Holy Communion is concerned, Martin Luther emphasises the 'Word and ordinance or command of $\mathrm{God}^{\prime 13}$ as that which effects and constitutes the sacrament, namely the institution by Christ himself. Arguments brought forward, especially those relating to the Swiss Reformation, repudiate a 'figurative' interpretation of the Words of Institution according to which their validity merely lay in their 'metaphorical relevance'. There should rather be an adherence to the literal sense of the Words of Institution. Therein lies the objective basis and existence of Holy Communion. Thus a mark of the difference between Zwingli's Zurich Reformation and Luther can be said to be that, in Switzerland, it is a question of 'remembrance rather than sacrifice', whereas in Wittenberg it is a question of the Christ's 'continually making himself present' (Korsch 2005:16). The basis for such selfpresentation is that, 'in Christ's apostolically attested words of the Last Supper, he speaks to the congregants himself' (Schwarz 2005:28). It needs to be emphasised, however, that, with Christ's Words of Institution, bread and wine are being identified with his body and blood in a unique way (Peters 1993:137-146), ${ }^{14}$ by means of which the impartation of the forgiveness of sin, the readmission into the fellowship of Christ and the reinforcement of a faith in constant need of strengthening are being put into effect. ${ }^{15}$

At the same time the katabatic direction of that which occurs remains of a formative nature; '... the act of Communion itself, together with Christ's promise of salvation and the administration of the body and blood of Christ under the species of bread and wine remains an act of devotion on Christ's behalf that is gratefully received by Christians'; they do however not become the subject of this process (Schwarz 2005:43).

Receiving the gifts of Holy Communion in the way that Christ himself has ordained this sacrament to be celebrated and re-enacted by Christians forms a constitutive part of the sacrament in view of the fact that it was instituted as a meal in ceremonial form; it is regarded as the testament of Christ, something that not even the Church is allowed to amend or alter. Reformatory opinion holds furthermore that this also comprises the demand for the laity Communion cup and the

\section{FC SD VIIII 62-65, BSLK 993f; 78, BSLK 1043.}

13.Large Catechism, The Sacrament of the Altar, 4, BSLK 708.

14.In this respect Gunther Wenz lags behind the main point of Lutheran Eucharistic theology by stating: 'The real presence of Jesus Christ is therefore indubitably to be defined as being personal presence', (Wenz, Theologie der Bekenntnisschriften, Vol. 1, 638) Peters (1993:134) regrettably and from the outset dismisses the insights he gained from Luther's texts as 'remaining tied to the Middle Ages'.

15.Large Catechism, The Sacrament of the Altar, 20-32, BSLK 711-714. liturgical execution 'in both kinds', a demand that is clearly in accordance with the Lord's mandate(Mt26,27;1.Kor 11,20ff) as well as Early Church practise. ${ }^{16}$ By the same token, receiving the body and blood of Christ 'with the mouth' must be regarded as a genuine component of Lutheran Eucharistic theology: The corporeal dimension of the sacramental ceremony must not be underestimated, seeing that it is a matter of the presence of Christ's sacrificial form in its 'holistic' relevance to us (Sasse 1979:50).

The celebration of Holy Communion is always also a celebration of the Church of Jesus Christ; the place of the sacrament is at the centre of God's people. The 'consecration' of the eucharistic gifts of bread and wine is executed in an all-encompassing liturgical event ('tota actio'). This includes the assembly of worshippers, the preparation of the gifts, their consecration with the Lord's Words of Institution, the distribution, reception, eating and drinking thereof, as well as the proclamation of salvation that Christ has secured and obtained with this act of self-offering. ${ }^{17}$

It is clear that increasingly differences arose with Luther's and Melanchton's conceptions of the Sacrament of the Altar, together with tensions between the theology of Württemberg and that of Wittenberg during the second half of the sixteenth century (Hund 2006:97-111). An evolving distancing from Luther can be discerned in Melanchton's statements, as well as the limited opportunities of communication that existed a limine 'between the classical philippistic concept and the position adhered to in Württemberg', for which Johannes Brenz and his scholars may serve as representatives. The tensions that existed from an early stage subsequently turned out to be fundamental differences that could apparently no longer be overcome. In the resolution of divergences and differences as it was inspired by Martin Chemnitz and implemented in the Formula of Concord, the communicatrio idiomatum realis is perceived as the 'context of events'; the real presence of the body and blood of Christ in the Sacrament of the Altar is based on the creational and omnipotent Word of Christ which also posits realities that human insight is unable to comprehend 'pre-eschatologically' (Hund 2006:701).

Legitimate endeavours do exist and pertain, however, with regards to a delineation of the institution, reality, meaning and effect of the Lord's Supper that is theologically and scripturally founded, appositely factual, conceptually accurate and undergoes a plausibility check to the greatest possible extent. According to the latest confessional text in the Book of Concord, this includes the real and substantially constituted presence of the body and blood of Christ along with its administration and distribution in union with the earthly elements, the corporeal 'partaking' of these gifts 'with the mouth' and the reception of exactly these gifts of the body and blood of Christ, regardless of the religious or moral disposition of the communicants (Kolb 2011:141).

16.Fundamentally important in this regard: CA XXII, BSLK 86 f.; ASm III 6, BSLK 450-452. 17.FC SD VII, BSLK 1000f. 


\section{Recent attempts by the Roman Catholic Church to reformulate the eucharistic presence, and its Criticism}

In recent Roman Catholic Eucharistic theology, and regarding the terms of reference of the - ostensibly no longer comprehensible - substance ontology, an attempt has been made, in the background of the transubstantiation theory, to bring about some kind of modification in order to retain their meaning; the objective was 'to do better justice to the personal character of the eucharistic mystery'. The 'Doctrine of Transignification or rather Transfinalisation' constitutes an attempt at complying with this objective (Faber 2002:114). In a sacramental context the elements are therefore transferred into another dimension of meaning or significance. The signal word for a redetermination of this nature is the concept of the 'real symbol'; it is meant to overcome the problems associated with the traditional concept of 'sign' (cf. Slenczka 1993:25). Towards that end it is being integrated into an event of personal encounter (Slenczka 1993:30). By way of contrast Pope Paul VI has emphasised the reconnection of the elements to an 'ontological redetermination' (Faber 2002:115).

In order to counter the risk of a purely subjective understanding, the term 'trans-institution' has been brought into the debate, in the sense of a 're-institution, during which God himself creates a new appropriation of being to the realities of bread and wine' (Hilberath in Faber 2002:115). The personal conception of the eucharistic event nonetheless also still prevails in the more recent interpretation, seeing that the case is put for a 'reconnection of Christ's somatic real presence with his personal presence' because the Eucharist was an 'event in which Jesus Christ is the subject who encounters us' (Faber 2002:115). The 'act of receiving' in eating and drinking is consequently interpreted as being Christ's 'expressive manner of self-offering', as 'Jesus' act of self-offering in bread and wine', to wit, the objective of which was 'not the new quality of bread and wine but rather the transformation of the person receiving them' (Faber 2002:116). Hence, claim can also be laid to an ecumenical 'consensus on the real presence of Jesus Christ in the eucharistic event'; it is only 'with regards to the How' that opinions are still divided (Faber 2002:117).

The capability of the more recent Roman Catholic models of interpretation regarding the eucharistic presence of the sacramental gifts to convey their intended meaning in the 21st century has admittedly been challenged by Notger Slenczka, seeing that 'according to the traditional understanding, the objectivity of a real presence under the species is at the core of the Eucharist' (Slenczka 1993:32) ${ }^{18}$ The phenomenology behind the Doctrine of Transignification, be it of a transcendental or existential nature, is viewed as being fundamentally different than the determinants of substance ontology, while being dismissed as ontologically inadequate at the same time (Slenczka 1993:542). It 'circumvents the ontology of substance' because it disputes its presumed 'the presumed integrity of the elements' (Slenczka 1993:539f); it attempts 'to determine the "essence" of being from the "finis" or rather from the "meaning" of being "for" a person' (Slenczka 1993:549). The implication of the redetermination of eucharistic reality is said to be to 'break the isolation of the real presence under the species as being a purely factual "presence" or "presentness" of Christ and to integrate the real presence into the context of an event aimed at the res tantum sacramenti, namely the unio fidelium cum Christo' (Slenczka 1993:558). From an ecumenical perspective these Roman Catholic theological approaches lead to the conclusion 'that real presence, by its internal structure, constitutes an intentional event and that its application and usage is not accidental but fundamental' (Slenczka 1993:559).

It has furthermore been pointed out that the 'assignment of the sacramental presence, the sacraments and the Church (as Christ's medium) in general to the implementation of the encounter between God and humans' constituted a 'strict parallel [...] to Luther's fundamental concerns' (Slenczka 1993:560). It was a matter of 'not viewing Real Presence as fact but rather seizing Real Presence as a mode for Christ's self-donation to the believer' (Slenczka 1993:570). Luther's theological concern was nevertheless towards a 'redetermination of language and reality' (Slenczka 2005:79-98). There can be no doubt: "The identification "This (bread) is my body" must, with all the components of the sentence, be understood literally and therefore as identification'. It is precisely this understanding that has however been obtained 'from the language of the Bible' (Slenczka 2005:95). It should remain question-able, however, whether it would consequently suffice to interpret 'Holy Communion as being an individual appropriation of the person of Christ in the direction towards faith, that is to say: as basis for a new conception of self' (Slenczka 2005:97).

\section{Recent determination attempts of evangelical origin}

Recent Lutheran attempts to interpret 'Real Presence' with regards to the Sacrament of the Altar are dominated by personal characterisations of the manner of Christ's presence. ${ }^{19}$

Albrecht Peters, following Luther in this respect, regards the 'sacrament as the summary of the entire Gospel' (Peters 1966:134). Accordingly, 'Luther venerates the Lord who is present in bread and wine' (Peters 1966:94). The verba testamenti do nonetheless constitute a revelatory process: 'the Lord, corporeally/present in the element, reveals himself in them to the communicants'; this process is understood to be Wordbased and personal (Peters 1966:87). 'The material, tangible and personal referents' are nevertheless 'equally present' (Peters 1966:110). Luther 'attests to a corporeal presence where exactly that which characterises bodily presentness has been taken away' (Peters 1966:98) or, to invert the perspective: 'A body is present like a spirit, and yet the essence of its 19.In the interest of brevity I confine myself to a selection from German theological literature of the past 50 years. 
physical being is not annulled' (Peters 1966:99). This corresponds to 'the belief in the Lord's presence' (102). For it is not a matter of a 'repraesentatio of salvific facts' but rather of the 'presence of the one who effects salvation' (Peters 1966:112). In this respect 'the Word is superordinate to the bodily eating with regards to the partaking' (Peters 1966:127), and the 'gift of the sacrament' was therefore 'no other than that of the Word, the totus vivus Christ in his person of God-human' (Peters 1966:134). The 'proprium of the Sacrament of the Altar' was therefore 'not the What of Christ's presence', but rather 'the How of this presence' (Peters 1966:139).

Hermann Sasse sees an indissoluble connection between Incarnation and Real Presence (Sasse 1979:114-121); for him, the incontrovertible certainty of the nature of what constituted the gift of the Sacrament of the Altar remains: 'It is the body that was born from his mother Mary, that died on the cross, that was buried, that rose from the grave, ascended to Heaven and is seated at the right hand of the Father [...]. This and nothing else is the Church's dogma of Holy Communion' (Sasse 1979:20). Consequently the manducatio oralis of the body and blood of Christ is 'consummate expression' of the 'actual incarnation' (Sasse 1979:24). He sees the facts of this matter already confirmed in the liturgy and theology of the Early Church: 'After consecration, bread and wine are body and blood of the Lord. Nothing else? No, nothing else' (Sasse 1979:26). Sasse finds the understanding of this factuality further propounded in the Wittenberg Concord of 1536, which 'presented the explicit confession that bread and wine were, truly and substantially, the body and blood of Christ' (Sasse 1979:76).

Ulrich Kühn fundamentally understands the sacraments to be 'symbolic communicative acts' (Kühn 1990:219) and 'reciprocal acts in faith, effected by the Spirit' (Kühn 1990:219) or 'acts of the Church of Christ'. This fundamental understanding also pertains to the Sacrament of the Altar (Kühn 1990:259). Within this ecclesial substantiation it provides 'reassurance of belonging [...] an experience of security, [...] a fresh start within the entanglements of guilt and violence' and is experienced as 'life shared as occurrence' (Kühn 1990:264). It is furthermore to be viewed as being 'also the work of the church', 'Christ's institution and gift', essentially only 'in the sense of a contextualised institution which binds together the actions of the pre-Easter Christ with those of the exalted Christ' (Kühn 1990:268). The fact that Christ constitutes the intrinsically solitary subject of the Eucharist and the 'meal-act' is at least obscured where Kühn is concerned, if 'the Church of Jesus that has gathered in the name of Jesus (that is to say in his spiritual presence)' is understood to be to be the one who is the actor, thereby awarding 'the ecclesiological dimension an even more fundamental role in co-constituting the specific real presence of Christ' (Kühn 1990:277, 284). He does however not want 'the assurance of the Lord's commitment to be present for our benefit and the granting of his communion with us to be brought into question' (Kühn 1990:293). As far as the determination of Real Presence is concerned, Kühn aligns himself with the Leuenberg Agreement to the effect that 'the personal understanding of the gift of Holy Communion and therefore the presence of Christ has become fundamental' (Kühn 1990:283). In this respect Holy Communion must be '[intention, locus and occurrence of the church's pivotal encounter with Christ and, at the same time, locus and occurrence where the church as fellowship is continually being re-established' (Kühn 1990:293). A 'symbolic execution' of this kind allows that which is being symbolised to be 'tangibly executed', 'communion with the Lord and with one another' (Kühn 1990:29). As much as the emphasis on the church-fellowship dimension that the Sacrament of the Altar also brings about is to be welcomed, a clear failure to clarify what determines that which constitutes the real presence can be discerned from the perspective of those committed to the Book of Concord.

To be endorsed a priori is Gunther Wenz's basic premise that, with Holy Communion, 'the Lord of the Supper is present as the Incarnate One, that is to say as the One who betook himself to the uttermost depths of finitude to reside with humanity' (Wenz 1988:159). More specifically it can be said that his presence is 'in a state of being sacrificed' (Kinder in Wenz 1988:159). Wenz declares the alternatives of 'substantialism and personalism, res presence or personal presence' to be 'over-hasty antitheses' (Wenz 1988:160), only to resolve them in a personally determined synthesis: 'The Eucharistic theology of the body and blood of Christ emphasises that the Lord is personally and effectively present in the fullness of his (hi)story where he is what he is' (Wenz 1988:161). The gift in the Lord's Supper is therefore the 'one person of the Christ who died for us', and 'not separate substances' (Wenz 1988:162). He reproaches a so-called 'repristinative Lutheranism' (Wenz 1988:192)20 for 'decidedly' wanting to 'interpret Real Presence as being res presence while explicitly seeking to differentiate the substantiality of the eucharistic gift from the personal nature of faith in the Word' (Wenz 1988:192). Wenz posits the 'pivotal content of all spiritual gifts', thus also those of the sacrament, to be 'the forgiveness of sins [...], for the sinner to be accepted into the fellowship of Christ' (Wenz 1988:43). It cannot be denied that, at the same time, this acceptance highlights ecclesial connections (Wenz 1988:256). Of course this view should not allow for the change in subject to be in evidence to the extent that the sacraments are regarded as being 'real-symbolic acts of faith of the church of Jesus Christ' (Wenz 1988:256). ${ }^{21}$ It did however constitute 'a non-negotiable Lutheran confession that the Incarnate Word can, in the Sacrament of the Altar and based on faith in the midst of our world, in immediate proximity, in genuine historicity that is relevant to us, that is to say in corporeality in the action of bread and wine being administered, be bodily grasped and held' (Wenz 1988:50).22 The katabatic structure of the sacrament is thereby indicated; however, this quotation, measured against the classical

20.Wenz counts Friedrich Wilhelm Hopf, Hermann Sasse and Ernst Sommerlath amongst these; cf. Wenz (1988:47-51); cf. also Kühn (1990:278-280); the incriminating stances addressed by Wenz and Kühn can be found bundled together incriminating stances addressed by Wenz and Kunn can be found, bundled togethe with others, in 'Vom Sakrament des Altars. Lutherische Beiträge zur Frage des
heiligen Abendmahls' (Sasse 1941).

21. With Wenz versus Kühn (1990:306)

22.Cf. Wenz with reference to Paul Althaus (1929:34) 'mere verbism' was, from a Lutheran point of view, admittedly not tenable (Wenz 1988:50). 
Lutheran determinations concerning the administration of the Eucharist and reception of the sacrament, misses the significance of both manducatio oralis as well as manducatio impiorum. When Wenz takes up devout reception as determinant of the elements via the verba testamenti, he speaks out against an 'isolated piety regarding the elements' as well as an 'actualism disregarding the elements' (Wenz 1988:55). It should however be borne in mind that the 'meal elements', in their capacity as vehicle for the body and blood of Christ that are administered precisely to be partaken with the mouth, become 'body-bread' and 'blood-wine', to use Luther's words. ${ }^{23}$

When Reinhard Schwarz, in taking up Lutheran ideas, suggests that 'Jesus Christ, the incarnate Son of God who died on the cross and was exalted by God after his resurrection, speaks his valid Word in the words of Holy Communion' (Schwarz 2005:47), then the following applies: Christ 'identifies himself' in precisely this manner 'through his self-offering by means of bread and wine' (Schwarz 2005:33). With this kind of presence the concept of 'personal presence' is given preference, however, and the concepts of 'Real Presence' and 'consubstantiation' deemed to be ineffectual (Schwarz 2005:46). It is said to be a matter of the re-presentation taking place 'in person' and the 'body and blood of Christ' not being able to 'become present as substances independent of the person of Christ' (Schwarz 2005:46). It was precisely for this reason that the body and blood of Christ could not be declared as being 'substances', seeing that 'they were present, not in substantial integrity, but rather in indissoluble union with the incarnate and exalted Son of God' (Wenz 1988:161). Even in the statement that Christ, 'with the Words of his Last Supper and in his bodily humanness, identifies himself with the gifts of bread and wine and imparts himself within the union of Communion Word and -gifts' (Schwarz 2005:47), Luther's insistence on the 'est' inadequately defined.

A side glance may also be cast on Hans-Martin Barth's attempt at placing and interpreting the Lord's Supper 'in the context of world religions' (Barth 2001:637-661). Where the institution of the Lord's Supper is concerned, he, too, prefers to regard it in a context of institution (Barth 2001:640) and cites current interpretations of Christ being sacramentally present (Barth 2001:641-645) as well as problems surrounding the concept of sacrifice (Barth 2001:645-647). He defines the significance of the Lord's Supper as being 'fellowship with Christ', as 'fellowship of believers amongst each other' and as 'fellowship of the new aeon' (Barth 2001:6550-6652). Barth understands the Word concerning the bread to be: 'He himself, for mankind, with his entire history, his entire being'; and the Word of the Communion cup: 'his life, his dying for them, the sinners' (Barth 2001:656). Barth does see certain connections to non-Christian rituals of a sacrificial or repast nature, but nevertheless finds a predomination of the 'special status that is religious-historically awarded to the Christian Eucharist' (Barth 2001:657-661). In doing so, he places special 23.Martin Luther: Vom Abendmahi Christi. Bekenntnis, WA 26, 444 f. emphasis on the 'consequences of eucharistic ethics' (Barth 2001:658). He holds out the possibility of a relativisation of traditional denominational controversies 'if the Words of Institution are not viewed in isolation but are rather applied to the entire eucharistic event, and are taken seriously within their fundamental soteriological and eschatological assertion' (Barth 2001:661). To deny church fellowship in the sense of 'full communion' is consequently 'sin' (Barth 2001:661). This seemingly so ecumenical assessment is in patent contradiction to the circumspect observation in the Charta Oecumenica: 'Fundamental differences in faith are still barriers to visible unity. There are different views of the church and its oneness, of the sacraments and ministries'. This ecumenically honest document justly continues: 'We must not be satisfied with this situation', concluding that the Church commits itself to 'persevere in seeking a common understanding of Christ's message of salvation in the Gospel' ${ }^{24}$

\section{Ecumenical interim findings}

After several years of debate of a predominantly bilateral nature on the understanding of Holy Communion or the Eucharist, an appeal was made in the German ecumene for the continued dialogue on Holy Communion/the Eucharist. ${ }^{25}$ Here, too, and in a comprehensive review, account was given of a 'broad consensus concerning the issue of real presence in the Eucharist' (Wood 2012:389-410). ${ }^{26}$ From the last four decades of ecumenical debate, the following statements are regarded as being both compatible and commensurable, and not contradictory. ${ }^{27}$

In the Anglican/Roman Catholic dialogue it is stated that:

Communion with Christ in the Eucharist presupposes his true presence, effectually signified by the bread and wine which, in this mystery, become his body and blood. [...]The elements are not mere signs; Christ's body and blood become really present and are really given. (The Windsor Statement: On Eucharistic Doctrine 1971, §§ 6; 9). (Cf. Wood 2012:397) ${ }^{28}$

Anglicans and Lutherans agreed on the following formulation:

Both Communions affirm the real presence of Christ in this sacrament, but neither seeks to define precisely how this happens. (Pullach Report 1972, § 68) ${ }^{29}$

In a joint position of Lutheran, Reformed and United Churches, it is stated that:

In the Lord's Supper the risen Jesus Christ imparts himself in his body and blood, given up for all, through his word of promise with

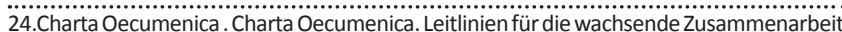
unter den Kirchen in Europa, in: ÖR 50 (2001), 506-514, here 508; also: Arbeitshilfe Charta Oecumenica. Anregungen zur Arbeit mit der Charta Oecumenica, Frankfurt/ Main, 2001). [= Guidelines for the Growing Cooperation among the Churches in Europe]

25.Nicht nachlassen im Dialog: Abendmahl/Eucharistie 2012, ÖR 61 (2012.), Booklet 4.

26. In the following I concentrate on the statements made on the presence (of the body and blood) of Christ in the Sacrament of the Altar and bypass those concerning sacrifice; cf. also Kasper (2011:173-198)

27.The quotations are chronologically listed for current contextual purposes.

28.Anglican/Roman-Catholic International Commission: The Eucharist, 1971(German version), in, DwÜ 1 Paderborn/Frankfurt am Main, 1983.

29.International Anglican/Evangelical-Lutheran Dialogue, The Pullach Report (German version), in: DwÜ 1, pp. 54-76, here 63f, cited in Wood (2012:395). 
bread and wine. He thus gives himself unreservedly to all who receive the bread and wine; faith receives the Lord's Supper for salvation, unfaith for judgment. (Leuenberg Agreement 1973, § 18) ) $^{30}$

The outcome of the Methodist and/or Roman Catholic discussions was formulated as follows:

Christ, in the fullness of his being, human and divine, is present in the Eucharist [...] This is a distinctive mode of the presence of Christ; it is mediated through the sacred elements of bread and wine, which within the Eucharist are efficacious signs of the body and blood of Christ. (Dublin Report, 1976, § 54) ${ }^{31}$

As a result of earlier Lutheran and/or Roman Catholic discussions the statement was made:

In the sacrament of Holy Communion Jesus Christ, true God and true man, is, with his body and blood, fully and entirely present under the sign of bread and wine. Catholic and Lutheran Christians jointly confess that they receive the real body and blood of the Lord in the Eucharist. (The Lord's Supper 1978, §§ 16; 62)32

A different conclusion was reached as a result of a Reformed and/or Roman Catholic dialogue:

... the presence of Jesus Christ [...] is at once sacramental and personal. [...] Thus we gratefully acknowledge that both traditions, Reformed and Roman Catholic, hold to the belief in the Real Presence of Christ in the Eucharist. (The Presence of Christ in Church and World, 1977, Phase I, $\S 83,91)^{33}$

In the World Council of Churches, convergence regarding the understanding of the Eucharist had been reached to the effect that, 'in the eating and drinking of the bread and wine, Christ grants communion with himself'; the Eucharist was defined as being a 'eucharistic meal' and as 'sacrament of the gifts' and, from the point of view of 'thanksgiving to the Father', as 'anamnesis or memorial of Christ', as 'invocation of the Spirit' and as 'communion of the faithful' (Lima Document, 1983). ${ }^{34}$ Thus it can also be stated that:

... the eucharistic meal is the sacrament of the body and blood of Christ, the sacrament of his real presence. [...] But Christ's mode of presence in the Eucharist is unique. Jesus said over the bread and wine of the Eucharist: 'This is my body ... this is my blood ...' What Christ declared is true, and this truth is fulfilled every time the Eucharist is celebrated. The Church confesses Christ's real, living and active presence in the Eucharist. ${ }^{35}$

Anglicans and Scandinavian Lutherans came to this joint conclusion:

30.Agreement between Reformation Churches in Europe (German version), in: DwÜ 3 Paderborn/Frankfurt am Main, 2003, pp. 724-731, cited in Wood (2012:395).

31.Report of the Joint Commission between the Roman Catholic Church and the World Methodist Council,(German version) in: DwÜ 1, pp. 423-453, here $437 f$ cited in Wood (2012:398).

32.Joint Roman Catholic/Evangelical-Lutheran Commission: The Lord's Supper (German version) Paderborn/Frankfurt/M. 1978, 17; 39; cf. Wood (2012:395).

33.Reformed/Roman Catholic Dialogue: The Presence of Christ in Church and World, 1977, Phase I, (German version) in: DwÜ 1, pp. 487-517, here 507, cited in Wood (2012:398).

34.Baptism, Eucharist and Ministry. Convergence statements of the Commission on Faith and Order of the World Council of Churches, (German version) in: DwÜ 1 paith and Order of the Wor

35.Baptism, Eucharist and Ministry. Convergence statements of the Commission on Faith and Order of the World Council of Churches, (German version) in: DwÜ 1, p. 560.
We believe that the body and blood of Christ are truly present, distributed and received under the forms of bread and wine in the Lord's Supper (Eucharist). In this way we receive the body and blood of Christ, crucified and risen, and in him the forgiveness of sins and all other benefits of his passion. (The Porvoo Common Statement, 1992, § 32 h) $)^{36}$

The following convergence was reached between Lutherans and Orthodox:

Lutherans and Orthodox take the Lord's words 'this is my body; this is my blood'... literally. They believe that in the Eucharist the bread and wine become Christ's body and blood to be consumed by the communicants. How this happens is regarded by both as a profound and real mystery. In order to approach that mystery, Orthodox and Lutherans have drawn on their respective theological traditions and developed different insights on what takes place. (1) Lutherans speak about Christ's 'real presence' in the Eucharist and describe Christ's body and blood as being 'in, with and under' the bread and wine [...] (2) Orthodox profess a real change (metabole) of the bread and the wine into the body and blood of Christ by the Words of Institution and the act of the Holy Spirit in the eucharistic anaphora. [...] The medieval doctrine of transubstantiation is rejected by both Orthodox and Lutherans. ${ }^{37}$

If one should compare these outcomes in their multilateral ecumenical context it becomes evident that they remain tension-filled, to say the least, thus calling their compatibility into question. How else should the explicit rejection of the 'medieval doctrine of transubstantiation' - which was admittedly no more than a theory until it was dogmatised by the Council of Trent - as it is implemented by Lutherans and Orthodox as opposed to the doctrine of the Roman Catholic Church, be understood by those for whom the resolutions of the Tridentium continue to be binding, even if they are being reformulated in the theological debates of the 21st century? How is the 'real presence of Christ in the Eucharist', as confessed by Catholics and Reformed Christians, deemed to be compatible with the confession of Catholics and Lutherans that they 'receive the real body and blood of the Lord in the Eucharist', or with the statement of Anglicans and Scandinavian Lutherans that 'the body and blood of Christ are truly present, distributed and received under the forms of bread and wine'? ${ }^{38}$ How is the statement, derived at after the Methodist/Roman Catholic discussion, that the 'sacred elements' in the celebration of the sacrament are 'efficacious signs of the body and blood of Christ' to be brought in alignment with the understanding arrived at with the Anglican and/or Roman Catholic discussions: 'The elements are not mere signs; Christ's body and blood become really present and are really given'? And how does one bring about 36.The Porvoo Common Statement (German version) DwÜ 2, Paderborn/Frankfurt am Main 2003, 749-777, here 766, cited in Wood (2012:396).

37.Lutheran-Orthodox Joint Commission, 13th Plenary, Bratislava (Slovakia), 2.-9. November 2006 (German version): Das Mysterium der Kirche. D/4. Die Heilige Eucharistie im Leben der Kirche, DwÜ 4, Paderborn/Leipzig (2012:514-519), here 516f, italics in the original; the document is in Wood (2012), as yet not incorporated.

38.It is evident that, at least with regards to the 16th century, there existed an irreconcilable conflict between the Lutheran and Reformed understanding of Holy irreconcilable conflict between the Lutheran and Reformed understanding of Holy Communion; cf. Jan Rohls (2005 51-78) see footnote 43), 51-78; a characteristic of he difference in assigning importance to this argument is that the Reformed churches regarded 'this perceived difference' as 'not so serious' that they would thereby deem the accordance with the Lutherans to be considerably more loosely; the semiotic term remains rather undetermined and the testimony falls clearly short of the terminology annulled at its roots' (Rohls 2005:78). 
a coherent correlation with all this and the fact that, resulting from the multilateral discussions, no relationship of the elements of bread and wine with Christ's body and blood is being effected? (Schöne 1996:45-49).

Walter Cardinal Kasper has, especially in the light of the results of the Lutheran and/or Roman Catholic dialogue, concluded that a number of 'unresolved' questions are still in need of further debate; these relate to 'the doctrinal formulation and the duration of the eucharistic presence', for instance, as well as the doctrine of the sacrificial character of the Mass, which is 'still a matter of dispute', but also the question as to Real Presence in terms of a 'transformation' of the elements of bread and wine (Kasper 2009:196). And he poses the specific question: 'Is Luther's own position on Real Presence [...] compatible with that of the Leuenberg Agreement, which is widely accepted by the Lutheran churches, and have the Lutheran-Reformed controversies on Real Presence been resolved?' (Kasper 2009:196). From the perspective of Lutherans who subscribe to the Book of Concord] the answer can only be: 'No!'; the Lutheran confessional understanding that the Lord's all-powerful Words of Institution effect the reality they indicate is not being retained in that said document but rather disputed (Klän 2012:84; cf. Sattler 2012:426).

But even if one analyses the statements of just one of the discussion partners in their various dialogue results, difficulties arise that are not easily resolved: How can it be deemed to be consonant with each other if, on the one hand, Lutherans establish that 'in the Eucharist the bread and wine become Christ's body and blood', and, on the other, that 'Jesus Christ, true God and true man, is, with his body and blood, fully and entirely present under the sign of bread and wine', while further maintaining that 'the risen Jesus Christ imparts himself in his body and blood, given up for all, through his word of promise with bread and wine'? These differences are only seemingly of little account. Even if the manner of transformation, as the result of which bread and wine now become the body and blood of Christ, is being rendered a 'mystery' in the course of Lutheran and/or Orthodox discussions, there remains an unmistakable tendency that can be identified in both statements: the elements of bread and wine do become Christ's body and blood. The differentiating depiction of the presence of Jesus Christ as God-Man, wherein the union with body and blood under the sign of bread and wine takes place as is jointly proclaimed by Lutherans and Catholics, conceives of this relation of the Fourth Lateran Council, which was adopted by the Confessio Augustana with the phrase 'under the species of bread and wine', thereby also invoking it as shared tradition. The Anglican-Lutheran formulation finds itself in closer proximity to this (admittedly of the Western Church) mode of agreement regarding the gifts of the Sacrament of the Altar in relation to the elements. However, the prepositional phrases in the determinants of the Leuenberg Agreement are especially lacking in the precise wording of the relation of the elements of bread and wine to the gift or gifts of body and blood. The convergences in the course of
Lutheran and/or Roman Catholic discussions of the last decades resulted in the statement that the belief 'in the eucharistic presence of Jesus Christ' is that of the 'exalted Lord'. ${ }^{39}$ This assertion does however clearly fall short of previous outcomes of Lutheran/Roman Catholic dialogue.

Regardless of the difficulties mentioned, attempts have been made in recent years to work on a 'Joint Declaration on the Lord's Supper' (Sattler 2012:411-428). Outlines for such a declaration have already been drawn up (Sattler 2012:415) and Kurt Cardinal Koch, the president of the Pontifical Council for Promoting Christian Unity, has already held out the prospect of such an option 2 years ago (Sattler 2012:413). It is not in dispute, however, that 'especially the controversies over the "sacrificial character" of Holy Communion and the Eucharist, as well as the different perceptions of Jesus Christ's 'real presence' in the act of the Communion liturgy or the Eucharistic celebration' are still deemed to be 'not ecumenically resolved' (Sattler 2012:417). It should however be strived for, by means of a 'delineation of differentiated consensus', to take important steps towards the goal of 'full fellowship of the Eucharist and Holy Communion of all Christians' (Sattler 2012:421, 411). From a Protestant perspective and with considerably less reservation, such a project is advocated as being 'ecumenically desirable and [...] reasonable and possible' (Nüssel 2012:437), seeing that, despite all undeniable disagreements, there existed 'no church-dividing differences' (Nüssel 2012:343). There admittedly still remained institutional and ecclesiological differences that needed to be resolved (Nüssel 2012:438).

The new Ecumenical Dogmatics of Wolfgang Beinert and Ulrich Kühn also contribute towards an ecumenical safeguarding of dialogue results, at least where the combined Roman Catholic/Protestant efforts are concerned, while simultaneously throwing the shortcomings of previous dialogue results into sharp relief (Beinert \& Kühn 2013). Cross-denominationally it can therefore be said about the Lord's Supper that: 'The explanatory words of Jesus regarding bread and wine must be understood [...] as the words of sacramental identification of body and bread, blood and wine' (Beinert \& Kühn 2013:659)..$^{40}$ The interpretation of 'body' and 'blood' attained on the basis of exegetical insights suggests a tendency towards a personal understanding: "With "body" (Gr. soma), the person of Jesus is meant in its corporeity, with "blood" (Gr. haima), a person as living corporeally - where blood is life' (Beinert \& Kühn 2013:659). ${ }^{41}$ This was linked to a soteriological interpretation, however, in which 'the relation to Jesus' death becomes tangible'; there was, on the other hand, no mention of a sacrifice on behalf of the church in the New Testament texts (Beinert \& Kühn 2013:659). With regards to the question of real presence, an observation is made concerning the Leuenberg Agreement, stating that 'a personalisation of the eucharistic gift is being effected' there,

39.Lutheran/Roman Catholic Commission on Unity: From Conflict to Communion. Joint Lutheran/Roman Catholic Commemoration of the Reformation in 2017 (German version), Leipzig/Paderborn $2014^{3}, 65$

40.Emphasis in original.

41.Emphasis in original. 
but, above all, 'that Christ's sacramental union with the "elements" of bread and wine has not been fully taken up, thereby not addressing a fundamental concern of the Lutheran tradition that has, at all times, adhered to the presence of Christ's body and blood "in, with and under" the bread and wine'; therefore 'the sacramental incorporation of the elements' was 'not given sufficient expression' (Beinert \& Kühn 2013:676). Nevertheless, what remains in the final analysis of the results for ecumenical relations is merely the twofold determination of boundaries that is supposed to obviate a 'distortion or rather dissipation of the confession regarding Christ's real presence in Holy Communion', as has been previously formulated in the joint Lutheran/Roman Catholic document 'Das Herrenmahl' (The Lord's Supper) of 1979: 'The eucharistic encounter with Christ' is said to be a 'mystery', the concept of which 'will probably never be adequately addressed' (Beinert \& Kühn 2013:677). ${ }^{42}$

If attempts are nonetheless made with ecumenical intent, an example of one solution that has been proposed is:

The 'presence' of Jesus Christ can be experienced in the Eucharist, which constitutes a symbolic act of God's steadfast loyalty to His covenant. Jesus himself has placed the eucharistic gifts into this interpretive framework. The essence of bread and wine is transformed with the remembrance ('memoria') of Jesus Christ: the interpretive words make present the origin-abiding context of reference of the symbolic act instituted by Jesus. The remembrance that takes place and is made present in the Spirit of God transforms the eucharistic gifts in Jesus' sense. Bread and wine are being retained as eucharistic gifts; however, their essence becomes a different one. They are now efficacious signs of Jesus' willingness to die, thereby letting the depth of God's love shine forth. (Sattler \& Nüssel 2004:209)

This statement presupposes the conviction that 'the category of "relation"' takes on 'a constitutive significance' with regards to the interpretation of Holy Communion or the Eucharist. Hence 'a personal, relational terminology' was deemed to be 'more helpful than the utilisation of naturalphilosophical concepts and material categories' (Sattler \& Nüssel 2004:205). The desired - and (supposedly) achieved convergence of the traditional understanding and interpretation of Real Presence is subsequently seen to lie therein that the 'denominational positions [...] will not differ where the devout acceptance of the true presence of Jesus Christ in the eucharistic event is concerned, but rather in the concrete delineation of the relation of this presence with the eucharistic gifts of bread and wine' (Sattler \& Nüssel 2004:209).

\section{A preliminary closing remark}

Referring to the 'mystery' as or rather in the 'sacrament', Hermann Sasse was already able to say: 'This is where all philosophy is at an end' (Sasse 1979:24). It must - and can also be exegetically argued, to wit, that the Words of Institution of the body and blood of Christ don't just refer to the person of Jesus, but to 'the body of Christ as the one delivered unto death, as the analogy to the word on the Communion cup shows' (Delling 2006:53; cf Kandler 2006:58). Following a systematic review it can be formulated thus: 'He is present 42.cf. Das Herrenmahi (Beinert \& Kühn 2013:17). with his body and blood, those proofs that make it clear to us that the sacrifice has been offered for us, which is however of present and continuous relevance before God'. It is consequently a matter of 'the presence of Christ's everlasting sacrifice in the context of the worshipping congregation' (Scaer 1980:181). Even if Lutheran theology shied away from connecting the idea of a sacrificial presence of Christ's body and blood with their sacramental presence (Roensch \& Schöne 1980:196) the gifts of the body and blood of Christ are inseparable 'from his person and the destiny of this person on Good Friday and Easter' (Kandler 1982:128). Subsequently the celebration of the Sacrament of the Altar can, and certainly with a modicum of boldness, be described as being a 'sacrificial banquet' (Kleinig 2003:11-13; cf. Stephenson 2008:41-58, 54).

This reality can likewise not be detached from the reality of the Incarnation of God in Jesus of Nazareth, so that, on the basis of Luther's understanding of the Sacrament of the Altar, the warning has to be sounded: 'The Incarnation of the eternal Son of God falls, Christian belief in its entirety falls, the Church of Christ falls with Real Presence' (Sasse 1979:77). Subsequently, in the Lutheran version of the proprium of the Sacrament of the Altar, this also leads to the determination that 'Christ gives himself, by means of his body and blood, to be partaken with the mouth' (Kandler 1982:140). For contemporary sensibilities it may well be that this perception and understanding and yes, truth, might 'appear to be offensive, namely that Christ, in his self-offering, is truly present in these gifts, that they are Christ's body and blood that are being partaken' (Brandt 2005:135). A 2004 study entitled 'Menschenstimmen zu Abendmahl und Eucharistie' (Human Voices and the Lord's Supper and the Eucharist) shows the extent to which the reminiscences of the classical, eucharistic-theological determinations of church traditions still exist in current ecclesiastical discussions, and how far the knowledge of the specifics relating to the eucharistic understanding of each denomination has receded in general, but especially with regards to the determination of the eucharistic gifts (Sattler \& Nüssel 2004:194-210). The clear and indeed 'disconcerting' (Rahner 2002:114) conclusion to be drawn is that, 'within an individual denominational tradition and in many cases, an exact knowledge of one's own argumentations in view of Jesus Christ's modes of presence in the liturgical eucharistic event cannot be ascertained, let alone an insight into the background of other confessions' (Sattler \& Nüssel 2004:200).

All churches and denominations face the challenge to bring that which they learn of Jesus Christ's sacramental presence from the New Testament, that which is formulated in binding fashion in their history as well as their authoritative documents and expressed in their eucharistic liturgy, and that which has been experienced and preserved in their own particular history of devoutness, back up for discussion again with fundamental scriptural testimony, and also with other Christian interpretations. At the same time, a fresh attempt in order for the theological and ecclesiastical convictions, not least one's own, to be heard and penetrated becomes an indispensable requirement for the respective different views to be understood. This forms part of the logic of dialogue. 
The Lutheran church, in its confessional documents and in the certainty that it speaks in accordance with the wording of Holy Scripture, decidedly advocates the true presence of the body and blood of Christ in the Sacrament of the Altar, and the dispensing of these gifts together with their benefits for those who receive the sacrament; it is this conviction that sees especially confessional Lutherans as shared by the views of the Roman Catholic church and the Orthodox churches in the East. ${ }^{43}$ With the reception of Holy Communion the Lutheran church moreover emphasises the unparalleled focus on the bestowal of God's salvation on the individual believer, as well as the fellowship-strengthening effect of the Sacrament of the Altar; it shares this understanding with many others. The Lord's Supper constitutes a standing invitation to strengthen one's trust in God, a renewal of one's rectified relationship with God and a deepening of one's union with Christ. ${ }^{44}$ It needs to be stressed, also and particularly with regards to the liturgical, ritual execution of the sacramental ceremony, 'that it is not merely bread and wine that are received, but, under their species, the body and blood of Christ' (Brandt 2005:136). The specific nature of Holy Communion lies precisely 'therein that, here, Christ gives his body and his blood as signs of his presence, to eat and drink for all who approach [the Lord's Table]' (cf. Kandler 1982:139). ${ }^{45}$

The Sacrament of the Altar is nothing else than the Gospel in corporeal form, that is to say the salvific self-donation of that which Jesus Christ has offered on the cross of Calvary so that we might have all good things from God. It will be the task of the Lutheran Church adhering to the Book of Concord to tirelessly introduce this message into contemporary ecumenical debate. If Jesus Christ, by the power of his Word, equates bread and wine into one with his body and blood in an unparalleled way, we not only experience something of Him, but receive Christ himself in the form of his sacrifice: his body and blood is the treasure that God himself has 'placed [upon] every one's ... table' ${ }^{46}$ We have and receive that what Christ says: 'This is my body. This is my blood of the covenant'. We should eat and drink that what Christ gives us: his holy body 'given for you'; his precious blood 'shed for you'. Here we receive and taste that which Christ distributes and administers: his body and blood, instituted and sacrificed for the redemption of the world. What Christ says posits the most absolute reality, has the most valid validity and is the most veritable truth.

It is precisely in this understanding that the Sacrament of the Altar is 'summa et compendium Euangelii'.$^{47}$ Or, to put it even more succinctly: 'This sacrament is the Gospel'. ${ }^{48}$

43.'Et comperimus non tantum romanam ecclesiam affirmare corporalen praesentiam Christi, sed idem et nunc sentire et olim sensisse graecam ecclesiam'. ApolCA X 2 , BSLK 248, 11-15, translated in English as, 'We know that not only the Romish, but also the Greek Church has taught the bodily presence of Christ in the Holy Supper'. FC SD VII 11, BSLK 976, 37-41; recently Stephenson, for instance Stephenson (2008:50).

44.Large Catechism, Part 5, 35, BSLK 714/Kolb/Wengert, p. 470.

45.Theologische Feststellungen zu den Arnoldshainer Abendmahlsthesen - Lutherische Theologische Hochschule, quoted in Kandler (1982:139).

46.Large Catechism, Part 5, 35.

47.Martin Luther, De captivitate Babylonica ecclesiae praeludium, 1520, WA 6, 525, 36. 48.Martin Luther: Vom Anbeten des Sakraments des heiligen Leichnams Christi, 1523, WA 11.

\section{Acknowledgements Competing interests}

The author declares that he has no financial or personal relationships which may have inappropriately influenced him in writing this article.

\section{References}

Agreement between Reformation Churches in Europe, 2003, 'Leuenberg concord', in DwÜ 3, Bonifatius, Paderborn. (in German)

Althaus, P., 1929, Luthers Abendmahlslehre, LutherJahrbuch 11, 2-42.

Angenendt,A., 2013, Offertorium. DasmittelalterlicheMeßopfer. Liturgiewissenschaftliche Quellen und Forschung 101, Aschendorff-Buchverlag, Münster.

Anglican/Roman-Catholic International Commission, 1983, The Eucharist, 1971, Dokumente wachsender Übereinstimmung 1, Bonifatius, Paderborn. (in German)

Baptism, Eucharist and Ministry, 1983, Convergence statements of the Commission on Faith and Order of the World Council of Churches, Dokumente wachsender Übereinstimmung 1, Bonifatius, Paderborn. (in German)

Barth, H.-M., 2001, Dogmatik. Evangelischer Glaube im Kontext der Weltreligionen. Ein Lehrbuch, Gütersloh, München.

Beinert, W. \& Kühn, U., 2013, Ökumenische Dogmatik, Evangälische Verlagsanstalt, Leipzig.

Biel, G., 1965-1967, in H. Oberman \& W.J. Courtney (eds.), Gabrielis Biel Canonis Missae Exposition, Lectio 37, Franz Steiner, Wiesbaden.

Brandt, R., 2005, 'Ob die Worte: “Das ist mein Leib" wohl feste stahn?', in Korsch (ed.), Die Gegenwart Jesu Christi im Abendmahl, pp. 123-138, Evangelische Verlaganstalt, Leipzig.

Delling, G., 2006, 'Abendmahl II. Urchristliches Mahl-Verständnis', Theologische Realenzyklopädie (TRE) I 47-553.

Die Bekenntnisschriften der evangelisch-lutherischen Kirche, Vandenhoeck Ruprecht, Göttingen 1930, 1967.

Faber, M.-E., 2002, Einführung in die katholischen Sakramentenlehre, Wissenschaftliche Buchgesellschaft (WBG), Darmstadt.

Greshake, G., 1997, 'Priester/Priestertum III', Systematisch, Theologische Realenzyklopädie 27, 422-431.

Hund, J., 2006, Das Wort ward Fleisch. Eine systematisch-theologische Untersuchung zur Debatte um die Wittenberger Christologie und Abendmahlslehre in den Jahren 1567 bis 1574, Forschungen zur Systematischen und Ökumenischen Theologie 114 Vandenhoek \& Ruprecht, Göttingen.

International Anglican/Evangelical-Lutheran Dialogue, 1983, The Pullach Report Dokumente wachsender Übereinstimmung 1, Bonifatius, Paderborn. (in German)

Joint Roman Catholic/Evangelical-Lutheran Commission, 1978, The Lord's Supper, Paderborn, p. 17, 39. (in German)

Kandler, H.-K., 1982, Christi Leib und Blut. Studien zur gegenwärtigen lutherischen Abendmahlslehre (Arbeiten zur Geschichte und Theologie des Luthertums, Neue Folge 2), Lutherisches Verlagshaus, Hannover.

Kandler, H.-K., 2006, 'Die Verwaltung des hl. Abendmahls, dogmatisch und praktischtheologisch', in J. Ringleben, J. Schöne \& K.-H. Kandler (eds.), Das Mahl Christi mit seiner Kirche: Lutherisch Glauben, Schriftenreihe des lutherischen Einigungswerks 4 pp. 58-59, Freimund, Neuendettelsau.

Kasper, W., 2009/2011, Die Früchte ernten. Grundlagen christlichen Glaubens im ökumenischen Dialog [Harvesting the fruits. Basic aspects of Christian faith in ecumenical dialogue], Bonafatius, Paderborn.

Klän, W., 2012, 'Bekenntnis und Sakramentsgemeinschaft - Anfragen an die Tragfähigkeit des Modells der "Leuenberger Konkordie" aus konkordienlutherischer Sicht', in W. Klän \& G. da Silva (eds.), Die Leuenberger Konkordie im innerlutherischen Streit. Internationale Perspektiven aus drei Konfessionen (Oberurseler Hefte. Ergänzungsband 9), pp. 74-91, Vandenhoek \& Ruprecht, Göttingen.

Kleinig, J.W., 2003, 'The Lord's Supper as a Sacrificial Banquet', Logia 12, 11-13.

Kolb, R., 2011, Die Konkordienformel. Eine Einführung in ihre Geschichte und Theologie, Oberurseler Hefte.Eergänzungsband 8, Ruprecht, Göttingen.

Kolb, R. \& Wengert, T. (eds.), 2000, The book of concord. The confessions of the Evangelical Lutheran Church, Fortress Press, Minneapolis, MN.

Korsch, D., 2005, 'Preface - Die Gegenwart Jesu Christi im Abendmahl', in D. Korsch (ed.), Die Gegenwart Jesu Christi im Abendmahl, pp. 11-18, Evangelische Verlaganstalt, Leipzig.

Kühn, U., 1990, Sakramente, Handbuch Systematischer Theologie 11, Gütersloher Verlagshaus, Gütersloh.

Luther, M., 1520, 'De captivitate Babylonica ecclesiae praeludium', WA 6, 525, 36.

Luther, M., 1523, 'Vom Anbeten des Sakraments des heiligen Leichnams Christi', WA 11, 431ff.

Lutheran-Orthodox Joint Commission, 2012, 13th Plenary, Bratislava (Slovakia), 2.-9. November 2006: Das Mysterium der Kirche. D/4. Die Heilige Eucharistie im Leben der Kirche, DwÜ 4, Bonifatius, Paderborn. (in German)

Lutheran/Roman Catholic Commission on Unity, 2014, From conflict to communion Joint Lutheran/Roman Catholic commemoration of the reformation in 2017 Leipzig, p. 65. (in German) 
Negel, J., 2005, Ambivalentes Opfer. Studien zur Symbolik, Dialektik und Aporetik eines theologischen Fundamentalbegriffs, Ferdinand Schöningh, Paderborn.

Nüssel, F., 2012, 'Ist eine "Gemeinsame Erklärung zum Herrenmahl" möglich und sinnvoll? Überlegungen aus evangelischer Sicht', Ökumenische Rundschau 61 429-439.

Peters, A., 1966, Realpräsenz. Luthers Zeugnis von Christi Gegenwart im Abendmahl (AGTL Vol. V), Luterische Verlaghaus, Berlin.

Peters, A., 1993, 'Kommentar zu Luthers Katechismen', in G. Seebass (ed.), Die Taufe, das Abendmahl, Vol. 4, pp. 137-146, Ruprecth \& Vanderhoek, Göttingen.

Pesch, O.H., 2010, Katholische Dogmatik aus öjkmumensicher Erfahrung, Vol. 2 Die Geschichte Gottes mit den Menschen. Ekklesiologie, Sakramentenlehre, Eschatologie, Grünewaldverlag, Ostfildern.

The Porvoo common statement, 2003, Dokumente wachsender Übereinstimmung 2 Bonifatius, Paderborn. (in German)

Rahner, K., 2002, 'Ökumenische Theologie der Zukunft', in K. Rahner (ed.), Einheit in Vielfalt. Schriften zur ökumenischen Theologie, Sämtliche Werke, Bd. 27, pp. 115 Lehmann Karl/Raffelt Albert, Freiburg.

Ratzinger, J., 1967, 'Das Problem der Transsubstantiation und die Frage nach dem Sinn der Eucharistie', Theologische Quartalsschrift 147, 129-158.

Reformed/Roman Catholic Dialogue: The Presence of Christ in Church and World, 1977, Phase I, Dokumente wachsender Übereinstimmung 1, Bonifatius, Paderborn, 1983. (in German)

Report of the Joint Commission between the Roman Catholic Church and the World Methodist Council, Dokumente wachsender Übereinstimmung 1, Bonifatius, Paderborn, 1983. (in German)

Ringleben, J., 2006, 'Der Sinn der Einsetzungsworte nach Luther', in J. Ringleben J. Schöne \& K.-H. Kandler (eds.), Das Mahl Christi mit seiner Kirche: Lutherisch Glauben, Schriftenreihe des lutherischen Einigungswerks 4, pp. 13-31, Freimund, Glauben, Schriftenr

Roensch, M. \& Schöne, J. (eds.), 1980, Die eine heilige christliche Kirche und die Gnadenmittel, Martin Luther, Erlangen.

Rohls, J., 2005, 'Geist und Zeichen. Die reformierte Abendmahlslehre in ihrer geschichtlichen Entwicklung', in D. Korsch (ed.), Preface - Die Gegenwart Jesu Christi im Abendmahl, pp. 51-78, Evangelische Verlaganstalt, Leipzig.
Sasse, H., 1979, Corpus Christi. Ein Beitrag zum Problem der Abendmahlskonkordie, Lutherische Blätter 117/118, Verlag der Ev.-Luth. Mission, Erlangen.

Sasse, H. (ed.), 1941, Vom Sakrament des Altars. Lutherische Beiträge zur Frage des heiligen Abendmahls, Dörffling \& Franke, Leipzig.

Sattler, D., 2012, 'Auf dem Weg zu einer "Gemeinsamen Erklärung zum Herrenmahl”? Eine offene Frage im Für und Wider', Ökumenische Rundschau 61, 426f.

Sattler, D. \& Nüssel, F., 2004, Menschenstimmen zu Abendmahl und Eucharistie. Erinnerungen - Anfragen - Erwartungen, Paderborn.

Scaer, D.P., 1980, 'Taufe und Herrenmahl im Leben der Kirche', in M. Roensch \& J. Schöne (eds.), Die eine heilige christliche Kirche und die Gnadenmittel, pp. 166-189, Martin Luther, Erlangen.

Schöne, J., 1996/2006, 'Das essbare Heil. Was Martin Luther vom heiligen Abendmahl bekennt', in J. Ringleben, J. Schöne \& K.-H. Kandler (eds.), Das Mahl Christi mit seiner Kirche: Lutherisch Glauben, Schriftenreihe des lutherischen Einigungswerks 4, pp. 33-49, Freimund, Neuendettelsau; reprinted in J. Schöne, 1996, Botschafter an Christi Statt, Versuche, Groß Oesingen.

Schwarz, R., 2005, 'Selbstvergegenwärtigung Christi', in D. Korsch (ed.), Die Gegenwart Jesu Christi im Abendmahl, pp. 19-50, Evangelische Verlaganstalt, Leipzig.

Slenczka, N., 1993, Realpräsenz und Ontologie. Untersuchungen der ontologischen Grundlagen der Transsignifikationslehre, Forschungen zur Systematischen und Ökumenischen Theologie 66, Vandenhoek \& Ruprecht, Göttingen.

Slenczka, N., 2005, 'Neubestimmte Wirklichkeit. Zum systematischen Zentrum der Lehre Luthers von der Gegewart Christi unter Brot und Wein', in D. Korsch (ed.), Preface - Die Gegenwart Jesu Christi im Abendmahl, pp. 79-98, Evangelische Verlaganstalt, Leipzig.

Stephenson, J.R., 2008, 'The Lutheran view', in G.T. Smith, The Lord's supper. Five views, pp. 41-58, Intervarsity Press, Downers Grove, IL.

Thomas Aquinas, to be provided by author

Wenz, G., 1988, Einführung in die evangelische Sakramentenlehre, Wissenschaftliche Buchgesellschaft (WBG), Darmstadt.

Wood, S.K., 2012, 'Die Eucharistie: Ökumenische Errungenschaften und bleibende Unterschiede', Ökumenische Rundschau 61, 389-410. 